
RESEARCH AND DEVELOPMENT

\title{
HIGEIA
}

http://journal.unnes.ac.id/sju/index.php/higeia

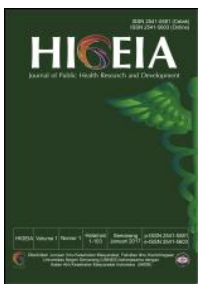

\section{Penggunaan Job Hazard Analysis dalam Identifikasi Risiko Keselamatan Kerja pada Pengrajin Logam}

\author{
Al Asyhar Wahyu Azady ${ }^{1 凶}$, Evi Widowati $^{1}$, Sri Ratna Rahayu ${ }^{1}$ \\ ${ }^{1}$ Jurusan Ilmu Kesehatan Masyarakat, Fakultas Ilmu Keolahragaan, Universitas Negeri Semarang, Indonesia
}

\section{Info Artikel}

Sejarah Artikel:

Diterima 7 Juni 2018

Disetujui 18 Oktober

2018

Dipublikasikan 30

Oktober 2018

\section{Keywords:}

Job Hazard Analysis (JHA),

Potential Hazard, Risk

\section{Analysis}

\section{DOI:}

https://doi.org/10.15294

/higeia.v2i4.23564

\begin{abstract}
Abstrak
Setiap tempat kerja selalu mempunyai risiko kemungkinan terjadinya kecelakaan dan penyakit akibat kerja. Pada tahun 2013 telah terjadi 406 kasus kecelakaan kerja di Kabupaten Boyolali, 372 pekerja $(91,6 \%)$ berhasil sembuh, 25 pekerja $(6,1 \%)$ sementara tidak mampu bekerja, 4 pekerja $(0,9 \%)$ mengalami cacat, dan 5 pekerja $(1,2 \%)$ meninggal dunia. Insiden kecelakaan dan cedera di tempat kerja dapat dikurangi dengan penggunaan Job Hazard Analysis. Penelitian ini dilaksanakan pada tahun 2018. Tujuan dari penelitian ini adalah untuk mengetahui potensi bahaya serta pengendalian yang tepat pada industri logam UD. A\&D dengan metode Job Hazard Analysis. Jenis penelitian ini adalah deskriptif kualitatif dengan pendekatan observasional. Hasil penelitian menunjukkan terdapat 46 bahaya dan 82 risiko yang teridentifikasi. Hasil penilaian risiko terdapat $24(29,6 \%)$ risiko rendah, 27 (32,9\%) risiko sedang dan risiko tinggi berjumlah 31 $(37,8 \%)$. Hasil penilaian dan pengendalian risiko dirancang dalam bentuk form Job Hazard Analysis. Kesimpulan penelitian ini adalah potensi bahaya yang ada belum dilakukan pengendalian secara optimal.
\end{abstract}

\section{Abstract}

Each workplace always has a risk of possible accidents and occupational diseases. In 2013 there were 406 work accident cases in Boyolali District, 372 workers (91.6\%) recovered, 25 workers (6.1\%) were unable to work, 4 workers (0.9\%) were disabled, and 5 workers (1.2\%) died. Incidents of accidents and workplace injuries can be reduced by the use of Job Hazard Analysis. This research was conducted in 2018. The purpose of this research is to know the potential danger and proper control on UD metal industry. A \& D with Job Hazard Analysis method. The type of this research is descriptive qualitative with observational approach. The results showed 46 hazards and 82 identified risks. Risk assessment results were 24 (29.6\%) low risk, 27 (32.9\%) medium and high risk $31(37.8 \%)$. The results of risk assessment and control are designed in the form of Job Hazard Analysis form. The conclusion of this research is the potential hazard that has not been done optimally.

E-mail: wahvu azadv@vahoo.co.id 


\section{PENDAHULUAN}

Kecelakaan kerja yang tinggi di setiap bidang pekerjaan disebabkan oleh multifaktor. Salah satu penyebab kecelakaan kerja yaitu tidak diterapkannya analisa potensi bahaya dan penilaian risiko terhadap bahaya-bahaya yang ada sehingga tidak terdapat pencegahan yang memadai terhadap bahaya yang kemungkinan dapat terjadi di perusahaan (Dualembang, 2017). Sebagai upaya pengendalian risiko kecelakaan dan penyakit akibat kerja, perlu dilakukan identifikasi sumber bahaya yang ada di tempat kerja dan dievaluasi tingkat risikonya serta dilakukan pengendalian yang memadai. Pengendalian risiko dilakukan pada seluruh bahaya yang ditemukan dalam proses identifikasi bahaya dan mempertimbangkan peringkat risiko untuk menentukan prioritas dan cara pengendaliannya, dalam menentukan pengendalian harus memperhatikan hierarki pengendalian mulai dari eliminasi, substitusi, pengendalian teknis, administratif dan penyediaan alat keselamatan yang disesuaikan kondisi organisasi dan jenis bahaya (Dankis, 2015).

Terdapat berbagai macam teknik yang dapat digunakan untuk melakukan analisis risiko yang ada di tempat kerja, baik kualitatif, semi maupun kuantitatif. Teknik analisis ini sangat bermanfaat untuk penekanan tingkat risiko tersebut sehingga tingkat kecelakaan dan penyakit akibat kerja terkurangi. Salah satu teknik analisis yang dapat diterapkan yaitu analisis bahaya pekerjaan atau Job Hazard Analysis (JHA). Teknik ini fokus kepada hubungan antara pekerja, pekerjaan, alat kerja, dan lingkungan kerja. Melalui kegiatan ini dapat diambil langkah-langkah untuk menghilangkan dan mengurangi tingkat risiko dari bahaya di tempat kerja. (OSHA 3071, 2002).

Sentra Industri Kerajinan Logam Cepogo Boyolali merupakan salah satu industri informal pengrajin logam yang ada di Indonesia. Sentra Industri kerajinan logam berada di Desa Cepogo Kabupaten Boyolali memproduksi berbagai kerajinan seperti hiasan interior rumah maupun yang lainnya yang berbahan baku utama logam yakni tembaga, alumunium, kuningan dan besi. (Laziardy, 2017). Industri logam UD. A\&D merupakan salah satu usaha kecil yang bergerak di bidang pembuatan produk berbahan logam. Produk yang dihasilkan dari industri ini antara lain: lampu hias, hiasan dinding, kaligrafi, meja, kursi, kubah, wastafel, bathtup, patung dll. Usaha ini berdiri sejak tahun 2009. Industri UD. A\&D memiliki 30 orang karyawan. Industri ini beroperasi dari hari senin hingga sabtu dengan jam kerja mulai pukul 08.00 hingga pukul 16.00 WIB. Bahan baku yang digunakan berupa plat baja yang berat dan terdapat banyak proses kerja baik manual maupun menggunakan mesin yang berisiko menimbulkan kecelakaan kerja.

Beberapa risiko kecelakaan kerja yang mungkin terjadi pada usaha ini diantaranya adalah kaki terkena gerinda saat proses penghalusan, terkena percikan bahan kimia dan terjepit mesin spinning saat proses pembentukan. Menurut hasil wawancara dengan pekerja, pada proses pembentukan dengan mesin spinning pernah terjadi kecelakaan yang mengakibatkan pekerja kehilangan beberapa jari akibat terpotong mesin. Selain itu, pada proses penghalusan juga pernah terjadi kecelakaan kerja sehingga membutuhkan beberapa jahitan di kaki akibat tersayat putaran roda gerinda. Rata-rata untuk tingkat keseringan terjadinya kecelakaan yaitu 2-3 kali tiap bulan, jumlah ini mungkin akan bertambah ketika permintaan barang dari buyers meningkat.

Observasi awal dilaksanakan pada tanggal 5 Agustus 2017, dtemukan beberapa tindakan tidak aman (unsafe act) yang dilakukan pekerja, misalnya tidak menggunakan alat pelindung diri dengan benar dan tidak mengembalikan peralatan kerja ke tempat semula setelah dipakai. Juga terdapat kondisi tidak aman (unsafe condition) seperti bahan baku yang menumpuk dan sisa material yang berserakan. Sejauh ini, Perusahaan telah melakukan tindakan rujukan dan pengobatan, pembuatan Standar Operasional Procedure (SOP), dan menyediakan Alat Pelindung Diri (APD) sebagai langkah intervensi, namun belum dilakukan secara konsisten karena belum 
dilakukan pengawasan dan pemberian sanksi bagi yang melanggar. Perusahaan ini juga belum pernah dilakukan pendataan mengenai kasus keselamatan dan tindakan analisis untuk menilai seberapa tinggi risiko di unit produksi tersebut. Tujuan dari penelitian ini yaitu untuk mengetahui potensi bahaya dan risiko yang terdapat pada industri logam UD. A\&D serta tindakan pengendalian yang dapat dilakukan untuk meminimalkan risiko kecelakaan kerja tersebut menggunakan metode Job Hazard Analysis (JHA).

\section{METODE}

Jenis penelitian ini adalah deskriptif kualitatif dengan pendekatan observasional. Fokus dalam penelitian ini adalah melakukan identifikasi, penilaian risiko dan memberikan rekomendasi pengendalian sebagai upaya pencegahan kecelakaan dan penyakit akibat kerja pada proses produksi di industri logam UD. A\&D Cepogo Boyolali. Penelitian ini bertujuan untuk mengetahui seberapa besar tingkat risiko keselamatan dan kesehatan pada proses produksi industri logam, kemudian merumuskan pengendalian melalui metode $J o b$ Hazard Analysis (JHA). Penulis menggunakan Job Hazard Analysis (JHA) sebagai metode untuk melakukan identifikasi bahaya, penilaian risiko dan pengendalian risiko. Beberapa keunggulan dan alasan mengapa penulis menggunakan metode JHA dibanding dengan metode lain adalah karena pendekatan JHA sangat mudah dipahami, tidak perlu melakukan training, dapat dengan cepat disesuaikan dengan pandangan individu yang berpengalaman, dapat diterapkan pada pekerjaan yang baru, atau proses dan prosedur kerja yang berubah-ubah, hasil dari analisis dapat digunakan untuk dokumentasi yang dapat digunakan untuk melatih pekerja baru dan dokumentasi JHA dapat digunakan sebagai bahan audit.

Sumber informasi dalam penelitian ini diperoleh dari data pimer dan sekunder. Data primer yang digunakan berupa data yang didapat dari hasil observasi dan wawancara langsung di tempat kerja dengan pihak manajemen serta pekerja di industri logam UD. A\&D Cepogo Boyolali. Sedangkan data sekunder meliputi dokumen-dokumen yang berisi informasi tentang keselamatan dan kesehatan kerja di perusahaan seperti alur proses produksi, Standar Operasional Procedure (SOP), Instruksi Kerja (IK) dan dokumen atau informasi pendukung lainnya.

Penelitian ini dilaksanakan pada bulan Februari hingga Maret 2018 dengan lokasi penelitian pada industri logam UD. A\&D Cepogo Boyolali. Informan dalam penelitian ini yaitu pemilik usaha, mandor dan pekerja. Berdasarkan jawaban dan saran dari pemilik usaha, kemudian dilakukan pengambilan informasi selanjutnya melalui teknik snowball sampling yang disesuaikan dengan kebutuhan dan di pilih sampai jawaban dari informan atau informasi yang didapat jenuh.

Instrumen atau alat pengumpul data yang digunakan dalam penelitian ini yaitu panduan wawancara dan lembar observasi berpedoman pada form JHA. Agar hasil wawancara dapat terekam dengan baik dan peneliti memiliki bukti telah melakukan wawancara kepada informan atau sumber data, maka diperlukan bantuan alat sebagai berikut: 1) Buku catatan, untuk mencatat hasil wawancara; 2) Alat perekam, digunakan untuk merekam segala interaksi dan komunikasi yang tidak sempat tercatat dalam penelitian; 3) Kamera, berfungsi untuk memotret ketika peneliti sedang melakukan pembicaraan dengan informan sehingga dapat meningkatkan keabsahan penelitian karena peneliti betul-betul melakukan pengumpulan data. Lembar observasi digunakan saat pengamatan langsung di lapangan. Lembar observasi pada penelitian ini dibuat berdasarkan dan berpedoman pada form JHA. Metode yang digunakan untuk melakukan identifikasi bahaya dan penilaian risiko keselamatan kerja mengacu pada Environmental Health \& Safety, Florida International University. Lembar observasi ini berfungsi untuk mencatat hasil observasi berkaitan dengan potensi bahaya di industri logam UD. A\&D Cepogo Boyolali.

Pengamatan yang dilakukan oleh peneliti adalah pengamatan terus terang atau tersamar, 
dimana peneliti melakukan pengumpulan data menyatakan terus terang kepada subjek penelitian sebagai sumber data bahwa peneliti sedang melakukan penelitian. Sehingga subjek penelitian yang diteliti mengetahui sejak awal hingga akhir tentang aktivitas peneliti. Teknik wawancara yang digunakan dalam penelitian ini adalah wawancara mendalam (in-depth interview). Wawancara mendalam dilakukan dengan menggunakan pedoman wawancara semi terstruktur yang ditujukan kepada informan yang sudah di tentukan sebelumnya, waktu pelaksanaan wawancara dilakukan pada saat jam istirahat kerja sehingga tidak mengganggu proses kerja atau proses produksi. Pengambilan data dilakukan secara terus menerus hingga tidak ada lagi informasi yang di dapatkan dari informan atau dapat dikatakan datanya jenuh. Pada penelitian ini, pemeriksaan keabsahan data menggunakan teknik triangulasi sumber dan triangulasi metode. Sedangkan analisis data menggunakan model dari Miles dan Huberman.

\section{HASIL DAN PEMBAHASAN}

Identifikasi bahaya pada seluruh proses kerja di industri UD. A\&D dilakukan dengan melakukan observasi pada pekerjaan yang dilakukan dalam tiap tahapan proses kerja dan melakukan wawancara terbuka terhadap pemilik usaha, mandor dan pekerja. Dalam melakukan identifikasi bahaya penulis menggunakan metode Job Hazard Analysis yang mengacu pada Environmental Health \& Safety, Florida International University. Penilaian risiko terhadap proses tersebut dilakukan dengan menggunakan kriteria probability (kemungkinan) dan severity (keparahan) untuk menentukan risk level (level risiko). Sejauh ini, Perusahaan telah melakukan tindakan rujukan dan pengobatan, pembuatan Standar Operasional Procedure (SOP), dan menyediakan Alat Pelindung Diri (APD) sebagai langkah intervensi, namun belum dilakukan secara konsisten karena belum dilakukan pengawasan dan pemberian sanksi bagi yang melanggar. Identifikasi bahaya dan penilaian risiko dilakukan pada seluruh tahapan proses produksi yaitu: proses persiapan bahan baku, pembuatan desain/mal, pemotongan bahan, pengelasan, penggerindaan, pemanasan, pembersihan, pembentukan, pewarnaan dan packing. Dari hasil penelitian ditemukan 46 potensi bahaya dan 82 jenis risiko. Menurut hasil identifikasi dan wawancara, semua tahapan pekerjaan pada proses produksi industri logam UD. A\&D mengandung potensi bahaya. Potensi bahaya yang terdapat di kerajinan meliputi: bahaya fisik, bahaya ergonomi, bahaya listrik, bahaya radiasi, bahaya ledakan, dan bahaya kimia. Seluruh potensi bahaya yang ada menimbulkan risiko dan dampak bagi pekerja, perusahaan maupun lingkungan. Oleh karena itu diperlukan rekomendasi pengendalian untuk menghilangkan/mengurangi risiko agar tidak menimbulkan kerugian bagi pekerja dan perusahaan.

Berdasarkan hasil identifikasi bahaya dan penilaian risiko, jumlah potensi bahaya yang terdapat pada 10 proses kerja yaitu 46, diantaranya yakni 16 potensi bahaya faktor fisik (34,7\%), 15 bahaya ergonomi (32,6\%), 8 potensi bahaya kimia $(17,3 \%), 3$ potensi bahaya listrik (6,5\%), 3 potensi bahaya ledakan $(6,5 \%)$ dan 1 potensi bahaya radiasi $(2,1 \%)$. Sedangkan dari 82 potensi risiko yang tersebar pada 10 proses produksi terdapat 24 risiko rendah $(29,6 \%), 27$ risiko sedang $(33,3 \%)$ dan 30 risiko tinggi (37\%).

Proses persiapan bahan baku merupakan kegiatan paling awal dari keseluruhan proses produksi. Pada proses ini ditemukan adanya potensi bahaya fisik dan ergonomi. Menurut hasil observasi, sebagian besar area proses kerja terdapat alat, material dan kabel yang berserakan. Sehingga menimbulkan risiko terjatuh, luka pada kaki dan memar. Perusahaan telah melakukan tindakan berupa pengendalian administratif dan APD. Pengendalian administratif dilakukan dengan memberikan instruksi agar berhati-hati dalam bekerja dan arahan tentang penggunaan APD berupa safety shoes. Sedangkan untuk pengendalian APD dengan menyediakan safety shoes bagi pekerja. Faktor penyebab kondisi berbahaya (unsafe condition) di perusahaan yaitu keadaan tidak 
Tabel 1. Hasil Identifikasi bahaya dan Penilaian Risiko Kerajinan UD. A\&D

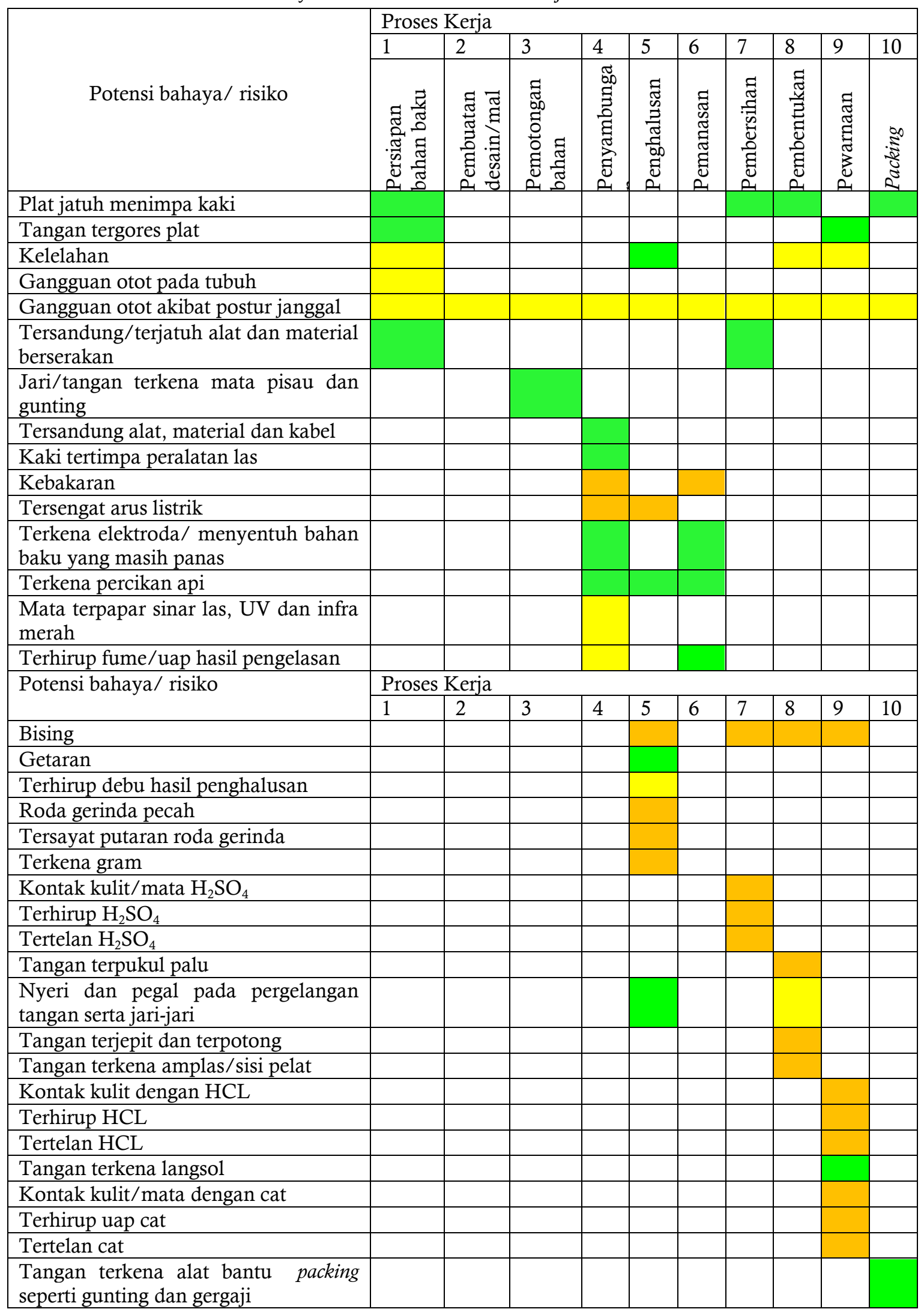


aman dari lingkungan kerja dimana tempat kerja kotor dan alat serta bahan material yang berserakan sehingga memungkinkan pekerja terjatuh. Sedangkan pada faktor penyebab tindakan bahaya (unsafe action) adalah suatu tindakan tidak aman pekerja seperti: tergesagesa dan kurang hati-hati saat berjalan, dan sengaja melanggar peraturan keselamatan yang diwajibkan dengan tidak menggunakan APD berupa safety shoes dikarenakan kurangnya pemahaman terhadap pentingnya penggunaan APD pada saat bekerja.

Proses kerja memindahkan bahan baku ini dilakukan secara manual, berat dari bahan baku (plat) yang dibawa oleh pekerja rata-rata 9$36 \mathrm{~kg} /$ lembar, hal ini tentu sangat berisiko sebab ketika tidak kuat menahan beban akibat bahan baku (plat) yang terlalu berat, maka bahan baku (plat) dapat terjatuh sehingga menimbulkan luka/cidera pada kaki. Rekomendasi pengendalian yang diberikan yaitu, melakukan housekeeping dengan baik dan mengubah desain tempat kerja, pengawasan penggunaan APD berupa safety shoes. Menurut hasil penelitian Pinggian (2016) tentang faktor-faktor yang berhubungan dengan kecelakaan kerja, menunjukkan bahwa penggunaan APD memiliki hubungan yang bermakna dengan kecelakaan kerja pada buruh angkut sampah di Kota Manado.

Pada proses pembuatan desain/mal, ditemukan adanya potensi bahaya fisik dan ergonomi. Salah satu risiko yang terjadi pada proses pembuatan desain/mal yaitu tergores plat. Perusahaan telah melakukan tindakan berupa pengendalian administratif dan APD. Pengendalian administratif dilakukan dengan memberikan instruksi agar berhati-hati dalam bekerja dan arahan tentang penggunaan APD berupa leather gloves. Leather gloves berfungsi untuk melindungi tangan dari permukaan kasar. Sedangkan untuk pengendalian APD dengan menyediakan leather gloves bagi pekerja. Faktor penyebab tindakan bahaya (unsafe action) di perusahaan yaitu tindakan tidak aman dari pekerja seperti: terburu-buru dan tergesa-gesa dalam melakukan pekerjaan dan tidak menggunakan APD berupa leather gloves yang tersedia disebabkan kurangnya pemahaman atau pengetahuan akan pentingnya penggunaan APD pada saat bekerja.

Rekomendasi yang dapat dilakukan yaitu dengan menyusun SOP pengangkatan plat, pelatihan manual handling, dan melakukan pengawasan, pelatihan serta mewajibkan penggunaan APD leather gloves kepada seluruh pekerja. Menurut hasil penelitian Pinggian (2016) tentang faktor-faktor yang berhubungan dengan kecelakaan kerja, menunjukkan bahwa penggunaan APD memiliki hubungan yang bermakna dengan kecelakaan kerja pada buruh angkut sampah di Kota Manado.

Pada proses pemotongan bahan terdapat faktor risiko terkena gunting plat/mata pisau mesin potong manual. Gunting plat digunakan untuk membuat potongan plat dengan desain yang tidak lurus/melengkung, sedangkan mesin potong manual digunakan untuk membuat potongan plat yang lurus. Dampak dari risiko ini menimbulkan luka gores, luka potong dan pendarahan pada tangan. Perusahaan telah melakukan tindakan berupa pengendalian administratif dan APD. Pengendalian administratif dilakukan dengan memberikan instruksi agar berhati-hati dalam bekerja dan arahan tentang penggunaan APD berupa metal gloves (sarung tangan logam). Sedangkan untuk pengendalian APD dengan menyediakan metal gloves bagi pekerja. Metal gloves berfungsi untuk melindungi dari benda tajam dan mencegah agar tangan tidak terluka/terpotong karenanya. Faktor penyebab kondisi berbahaya (unsafe condition) yaitu keadaan tidak aman dari peralatan kerja dimana tidak terdapat pengaman dan safety sign pada mesin potong manual. Faktor penyebab tindakan bahaya (unsafe action) di perusahaan yaitu tindakan tidak aman dari pekerja seperti: tidak menggunakan APD berupa metal gloves yang tersedia dan kurang berhati-hati di dalam bekerja.

Rekomendasi pengendalian yang diberikan yaitu: Menyusun SOP tentang pembentukan, memasang safety sign pada mesin, memberi pengaman pada mesin potong manual, melakukan pelatihan, pengawasan dan mewajibkan penggunaan APD berupa metal 
gloves untuk melindungi tangan dari mata pisau mesin potong manual. Menurut hasil penelitian Pinggian (2016) tentang faktor-faktor yang berhubungan dengan kecelakaan kerja, menunjukkan bahwa penggunaan APD memiliki hubungan yang bermakna dengan kecelakaan kerja pada buruh angkut sampah di Kota Manado.

Pada proses penyambungan terdapat 2 cara, yaitu memakai las dan timah patri, dari proses tersebut menimbulkan bahaya fisik, listrik, ergonomi, ledakan, kimia dan radiasi. Bahaya radiasi yang ditimbulkan dari proses pengelasan berasal dari glare (silau), cahaya tampak, sinar UV dan infra merah dari elektroda yang kontak dengan logam. Percikan bunga api berasal dari proses pengelasan menghasilkan radiasi sinar ultraviolet (Dixon, 2004).

Bahaya radiasi dari pajanan ultraviolet dapat menyebabkan photokeratitis dan conjungtivitis. Pengendalian yang telah dilakukan perusahaan yaitu pengendalian administratif dan penggunaan APD. Pengendalian administratif berupa instruksi agar berhati-hati dalam bekerja dan arahan tentang penggunaan APD. Sedangkan untuk pengendalian APD dengan menyediakan safety googles, welding mask, welding shield dan welding gloves.

Berdasarkan faktor penyebab tindakan bahaya (unsafe action) yaitu tindakan tidak aman dari pekerja karena sengaja melanggar peraturan keselamatan yang diwajibkan dengan tidak menggunakan alat pelindung diri, sehingga berisiko terpajan radiasi yang memberikan efek terhadap kesehatan pekerja.

Risiko dari bahaya radiasi berada pada tingkat risiko yang tinggi. Sehingga diperlukan pengendalian untuk menghilangkan atau mengurangi risiko tersebut. Rekomendasi pengendalian yang diberikan adalah memasang SOP pengelasan di tempat kerja, menyediakan kacamata berlensa (untuk melindungi dari bahaya radiasi sinar), peningkatan pengetahuan terkait dengan cara bekerja yang aman dan mengantisipasi bahaya yang muncul dari pengelasan serta pengawasan penggunaan APD di tempat kerja.
Pada proses penghalusan menggunakan gerinda, hasil identifikasi menunjukkan adanya bahaya listrik, fisik, kimia dan ergonomi. Salah satu risiko yang ditimbulkan dari kegiatan penghalusan yaitu getaran yang berasal dari putaran mata gerinda. Getaran dari alat tersebut menimbulkan getar pada tangan (hand arm vibration) yang menyebabkan kesemutan dan gangguan syaraf tepi. Berdasarkan pengamatan lapangan dan wawancara dengan pekerja, pengendalian yang telah dilakukan perusahaan yaitu pengendalian administratif dan penggunaan APD. Pengendalian administratif berupa instruksi agar berhati-hati dalam bekerja dan arahan tentang penggunaan APD berupa sarung tangan anti getaran. Sedangkan untuk pengendalian APD dengan menyediakan sarung tangan anti getaran. Faktor penyebab tindakan bahaya (unsafe action) yaitu tindakan tidak aman dari pekerja karena tidak menggunakan APD berupa sarung tangan anti getaran.

Rekomendasi pengendalian yang diberikan adalah memberikan pengetahuan kepada pekerja untuk tidak mengenggam peralatan terlalu keras (genggam kuat namun tidak ketat agar getaran tidak merambat), maintenance mesin secara rutin, pengawasan terkait penggunaan APD berupa sarung tangan anti getaran untuk meminimalisir getaran pada tangan. Menurut Odenwald (2014), penggunaan alat pelindung diri berupa sarung tangan dapat menurunkan tonus otot dan efek negatif yang ditimbulkan oleh pajanan getaran.

Pada proses pemanasan, hasil identifikasi menunjukkan adanya bahaya fisik, ledakan, kimia dan ergonomi. Bahaya ledakan pada proses pemanasan ledakan terjadi akibat kebocoran selang tabung gas akibat kontak dengan mesin gerinda atau terkena api pada tungku pemanasan. Dampak dari bahaya ledakan mengakibatkan luka bakar, kerugian materiil, pencemaran lingkungan, kebakaran, bahkan hingga berujung pada kematian. Perusahaan telah melakukan tindakan berupa pengendalian administratif dan APD. Pengendalian administratif dilakukan dengan memberikan instruksi agar berhati-hati dalam bekerja dan arahan tentang penggunaan APD. 
Sedangkan untuk pengendalian APD dengan menyediakan seragam las, leather gloves (sarung tangan kulit), apron, safety googles dan welding shield. Risiko dari bahaya ledakan memiliki tingkat risiko yang tinggi. Sehingga perlu dilakukan rekomendasi pengendalian untuk menghilangkan/mengurangi risiko tersebut.

Rekomendasi pengendalian yang diberikan untuk bahaya ledakan adalah memisahkan tabung asitelin berisi di ruang khusus, menempatkan tabung gas pada tempat yang aman, melakukan pelatihan tanggap darurat dan peningkatan pengetahuan terkait bahaya ledakan, penyediaan alat pemadam kebakaran dengan jenis serbuk kering (dry chemical), gas (CO2), dan busa serta menyediakan dan memasang safety sign, SOP pengelasan dan pemanasan serta di tempat kerja yang mudah terlihat. Sesuai dengan penelitian Putri (2017) tentang hubungan antara pengetahuan, praktik penerapan SOP, praktik penggunaan APD dan komitmen pekerja dengan risiko kecelakaan kerja di PT X Tangerang, bahwa ada hubungan antara variabel praktik penerapan SOP dengan risiko kecelakaan kerja yang tinggi.

Pada proses pembersihan, hasil identifikasi menunjukkan adanya bahaya fisik, kimia dan ergonomi. Salah satu risiko pada proses ini yaitu terhirup uap bahan kimia $\left(\mathrm{H}_{2} \mathrm{SO}_{4}\right.$ dan $\left.\mathrm{HCL}\right)$ yang dioleskan ke permukaan kerajinan. Dampak dari uap tersebut dapat menyebabkan iritasi pernapasan (seperti gejala sengau, nausea, pening dan sakit kepala), iritasi mata (kemerahan). Dalam jangka paparan yang lama dapat membuat kerusakan pernapasan, pandangan kabur dan pajanan yang berlebih dapat mengakibatkan kerusakan sistem saraf dan otak. Perusahaan telah melakukan tindakan berupa pengendalian administratif dan APD. Pengendalian administratif dilakukan dengan memberikan instruksi agar berhati-hati dalam bekerja dan arahan tentang penggunaan APD berupa masker respirator. Sedangkan untuk pengendalian APD dengan menyediakan respirator. Masker respirator berfungsi untuk melindungi saluran pernafasan dari debu, asap, uap, gas berbahaya dan partikel berbahaya lainnya yang mungkin ditemukan di lingkungan kerja. Risiko terhirup uap kimia memiliki tingkat risiko yang tinggi, sehingga memerlukan pengendalian untuk menghilangkan atau mengurangi risiko tersebut. Pengendalian yang dilakukan oleh perusahaan yaitu dengan menyediakan respirator dan MSDS.

Rekomendasi pengendalian yang diberikan untuk iritasi gangguan pernafasan akibat menghirup gas atau uap kimia yaitu melakukan tindakan pengendalian atau pengurangan risiko dengan sosialisasi dan pelatihan penggunaan APD berupa safety googles dan respirator yang benar bagi pekerja, penanganan bahan kimia, memasang MSDS, instruksi kerja waste management dan SOP pembersihan dan pewarnaan pada tempat kerja untuk meningkatkan kepatuhan pekerja dan mengurangi tingkat kecelakaan kerja. Sesuai dengan penelitian Putri (2017) tentang hubungan antara pengetahuan, praktik penerapan SOP, praktik penggunaan APD dan komitmen pekerja dengan risiko kecelakaan kerja di PT X Tangerang, bahwa ada hubungan antara variabel praktik penerapan SOP dengan risiko kecelakaan kerja yang tinggi. Rekomendasi pengendalian ini mengacu pada UU No. Tahun 1970 pasal 13 tentang keselamatan kerja, yaitu kewajiban bila memasuki tempat kerja, Kepmenaker. 333/MEN/1989 tentang diagnosis dan pelaporan penyakit akibat kerja, Kepmenaker. 187/MEN/1999 tentang pengendalian bahan kimia berbahaya, PP No. 18 tahun 1999 revisi PP 101/2014 tentang pengendalian sampah B3 padat/non organik.

Pada proses pembentukan hasil identifikasi menunjukkan adanya bahaya fisik dan ergonomi. Salah satu risiko dari proses pembentukan menggunakan mesin spinning yaitu jari tangan terjepit/terpotong saat mengoperasikan mesin spinning. Dampak dari penggunaan mesin spinning yaitu menyebabkan luka gores, pendarahan dan luka potong pada tangan. Selain itu, pada proses pembentukan juga terdapat risiko kebisingan yang berasal dari penggunaan palu dan mesin spinning. Kebisingan dapat menimbulkan dampak berupa 
gangguan komunikasi, rasa tidak nyaman, gangguan dan penurunan fungsi pendengaran serta kecelakaan kerja. Kebisingan dengan pajanan terus menerus dapat menyebabkan sensasi suara gemuruh dan berdenging hingga menyebabkan ketulian (Kurniawan, 2008). Perusahaan telah melakukan tindakan berupa pengendalian administratif dan APD. Pengendalian administratif dilakukan dengan memberikan instruksi agar berhati-hati dalam bekerja dan arahan tentang penggunaan APD berupa metal gloves (sarung tangan logam). Sedangkan untuk pengendalian APD dengan menyediakan metal gloves bagi pekerja.Risiko dari tangan terjepit/terpotong mesin spinning berada pada tingkat risiko yang tinggi. Sehingga memerlukan upaya pengendalian untuk menghilangkan/mengurangi risiko tersebut.

Rekomendasi pengendalian yang diberikan yaitu menyusun dan memasang SOP pembentukan di tempat kerja yang mudah terlihat, memberi pengaman pada mesin untuk mencegah tangan terjepit/terpotong, melakukan pengawasan kepada pekerja terkait penggunaan APD berupa metal gloves dan memasang safety sign pada mesin. Keberadaan safety sign di mesin spinning menurut standar safety sign ANSI Z535.4 2007, berdasarkan situasi bahaya yang menginstruksikan pesan keselamatan untuk melindungi pekerja maupun properti dari risiko kerugian belum sesuai dengan risiko bahaya yang ada di tempat kerja. Hal tersebut karena tidak ada sama sekali safety sign yang terpajang di mesin spinning, yang mengindikasikan adanya tanda risiko bahaya sesuai dengan identifikasi yang dilakukan.

Hasil identifikasi pada proses pengecatan menunjukkan adanya bahaya kimia, ergonomi dan fisik. Salah satu risiko yang terjadi dari kegiatan pengecatan yaitu terkena bahan-bahan kimia. Kontak bahan kimia $\left(\mathrm{H}_{2} \mathrm{SO}_{4}\right.$ dan $\left.\mathrm{HCL}\right)$ dengan kulit dapat menyebabkan iritasi, luka bakar pada tangan, dermatitis kontak dan kuku menjadi tipis. Kontak kulit dengan cat, tiner dan clear dapat menyebabkan iritasi kontak dermatitis (kulit kering dan pecah-pecah). Perusahaan telah melakukan tindakan berupa pengendalian administratif dan APD.
Pengendalian administratif dilakukan dengan memberikan instruksi agar berhati-hati dalam bekerja dan arahan tentang penggunaan APD berupa safety googles, masker respirator, sarung tangan karet/PVC. Sedangkan untuk pengendalian APD dengan menyediakan safety googles, masker respirator, sarung tangan karet/PVC. Risiko dari kontak kulit dengan bahan kimia memiliki tingkat risiko yang tinggi. Sehingga perlu dilakukan rekomendasi pengendalian untuk menghilangkan/mengurangi risiko tersebut.

Rekomendasi pengendalian yang diberikan untuk iritasi akibat kontak dengan bahan kimia yaitu melakukan tindakan pengendalian/pengurangan risiko dengan benar bagi pekerja, penanganan bahan kimia, memasang MSDS, instruksi kerja waste management dan SOP pewarnaan pada tempat kerja untuk meningkatkan kepatuhan pekerja, pengawasan, pelatihan dan mewajibkan penggunaan APD safety googles, masker respirator, sarung tangan karet/PVC kepada pekerja. Sesuai dengan teori dari Rijanto (2011), bahwa pada waktu melaksanakan pekerjaan, badan kita harus benar-benar terlindung dari kemungkinan terjadinya kecelakaan. Untuk melindungi diri dari risiko yang ditimbulkan dari akibat kecelakaan maka badan kita perlu menggunakan alat-alat pelindung ketika melaksanakan suatu pekerjaan. Rekomendasi pengendalian ini mengacu pada UU No. Tahun 1970 tentang keselamatan kerja, Kepmenaker. 333/MEN/1989 tentang diagnosis dan pelaporan penyakit akibat kerja, Kepmenaker. 187/MEN/1999 tentang pengendalian bahan kimia berbahaya, PP No. 18 tahun 1999 revisi PP 101/2014 tentang pengendalian sampah B3 padat/non organik.

Hasil identifikasi pada proses packing menunjukkan danya bahaya fisik dan bahaya ergonomi. Salah satu risiko dari kegiatan ini yaitu terkena alat packing seperti: palu, paku, tang dan gergaji. Dampak dari risiko tersebut yaitu luka pada tangan dan memar. Perusahaan telah melakukan tindakan berupa pengendalian administratif dan APD. Pengendalian administratif dilakukan dengan memberikan 
instruksi agar berhati-hati dalam bekerja dan arahan tentang penggunaan APD berupa leather gloves (sarung tangan kulit). Sedangkan untuk pengendalian APD dengan menyediakan leather gloves bagi pekerja. Leather gloves berfungsi untuk melindungi tangan dari permukaan kasar.

Faktor penyebab tindakan bahaya (unsafe action) di perusahaan yaitu tindakan tidak aman dari pekerja seperti: terburu-buru dan tergesagesa dalam melakukan pekerjaan dan tidak menggunakan APD berupa leather gloves yang tersedia dikarenakan kurangnya pemahaman terhadap pentingnya penggunaan APD pada saat bekerja, sebagian besar pekerja menganggap bahwa tidak perlu menggunakan APD pada saat bekerja karena faktor ketidaknyamanan saat bekerja sehingga dianggap mengganggu produktivitas pekerjaan.

Rekomendasi pengendalian yang diberikan adalah melakukan pengawasan terkait dengan penggunaan APD leather gloves. Sesuai dengan teori dari Rijanto (2011), bahwa pada waktu melaksanakan pekerjaan, badan kita harus benar-benar terlindung dari kemungkinan terjadinya kecelakaan. Untuk melindungi diri dari risiko yang ditimbulkan dari akibat kecelakaan maka badan kita perlu menggunakan alat-alat pelindung ketika melaksanakan suatu pekerjaan.

\section{PENUTUP}

Potensi bahaya yang terdapat pada 10 proses kerja yaitu 46, diantaranya yakni 16 potensi bahaya faktor fisik $(34,7 \%), 15$ bahaya ergonomi $(32,6 \%), 8$ potensi bahaya kimia $(17,3 \%), 3$ potensi bahaya listrik $(6,5 \%), 3$ potensi bahaya ledakan $(6,5 \%)$ dan 1 potensi bahaya radiasi $(2,1 \%)$. Sedangkan dari 82 potensi risiko yang tersebar pada 10 proses produksi terdapat 24 risiko rendah $(29,6 \%), 27$ risiko sedang (33,3\%) dan 30 risiko tinggi (37\%). Jenis pengendalian bahaya yang sudah dilakukan meliputi engginering control, administratif dan penyediaan APD. Pengendalian yang diperlukan yaitu menyediakan APAR dan meningkatkan pengetahuan tentang cara bekerja yang aman serta pengawasan APD terhadap pekerja.

Saran untuk penelitian selanjutnya yaitu perlu dilakukan penelitian dengan metode yang berbeda, mengembangkan instrumen yang ada dan menambah jumlah informan yang diwawancarai.

\section{DAFTAR PUSTAKA}

Dankis, NDV. 2015. Risk Assessment Perusahaan Export Sepatu pada Bagian Line Upper PT. $\mathrm{X}$. The Indonesian Journal of Occupational Safety and Health, 4 (1): 22-32.

Dixon A.J., and Brian F Dixon. (2004). Utraviolet Radiation from Welding and Possible Rsk of Skin and Ocular Malignancy. MJA. 181(3):155-157.

Dualembang, S. 2017. Analisis Penilaian Risiko Terhadap Potensi Bahaya Pekerjaan dengan Metode Job Safety Analysis pada Pekerja Bagian Proses Produksi PT. Kerismas Witikco Makmur Bitung. Media Kesehatan 9 (3): 1-10.

Kurniawan B. (2008). Hubungan Radiasi Gelombang Elektromagnetik Dan Faktor Lain Dengan Keluhan Subjektif pada Tenaga Kerja Industri Elektronik GE di Yogyakarta. Jurnal Promosi Kesehatan Indonesia 3 (2): 127-133.

Laziardy, M., 2017. KEBISINGAN TERHADAP KELELAHAN KERJA PADA PEKERJA LOGAM BAGIAN PRODUKSI. HIGEIA (Journal of Public Health Research and Development), 1(2): 58-64.

Odenwald, Stephan; Krumm, Dominik; (2014). effects of elastic compression sleeves on the biodynamic response to external vibration of the hand-arm system, elsevier. Procedia Engginering, 72 (2014): 114-119.

OSHA 3071. 2002. Job Hazard Analysis. USA: U.S. Departement Labour.

Pinggian, D. 2016. Faktor-faktor yang Berhubungan dengan Kecelakaan Kerja pada Buruh Angkut Sampah di Kota Manado. Communitty Health. 1 (1): 17-25.

Putri, AF. 2017. Hubungan antara pengetahuan, praktik penerapan SOP, praktik penggunaan APD dan komitmen pekerja dengan risiko kecelakaan kerja di PT $X$ Tangerang. Jurnal Kesehatan Masyarakat (e-journal). 5 (3): 269-277.

Rijanto, B. 2011. Pedoman Pencegahan Kecelakaan di Industri. Mitra Wacana Media: Jakarta. 